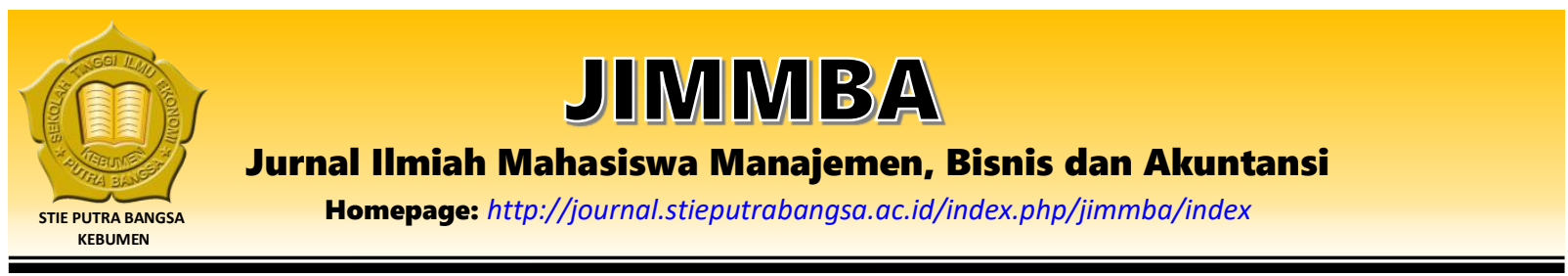

\title{
Pengaruh Kepemimpinan Islami dan Etika Kerja Islam Terhadap Kinerja dengan Motivasi Kerja Sebagai Variabel Intervening
}

\author{
Siti Khotijah', Irfan Helmy ${ }^{2}$ \\ 1,2Universitas Putra Bangsa \\ sitik0110@gmail.com
}

\section{ARTICLE INFO}

Article History:

Received: June $1^{\text {th }} 2021$

Accepted: July $10^{\text {th }} 2021$

Published: July $31^{\text {st }} 2021$

Keywords:

Islamic Leadership, Islamic

Work Ethic, Work

Motivation, Performance

\begin{abstract}
This study aims to examine the effect of Islamic leadership and Islamic work ethic on performance with work motivation as an intervening variable. The variables in this study consisted of three types of variables, namely independent variables which included Islamic leadership and Islamic work ethics. The dependent variable includes performance and the intervening variable, namely work motivation. The population in this study were PNS teachers at MTs Negeri 5 Kebumen, amounting to 48 people. The sampling technique is a total sampling because the number of respondents is relatively small so that the entire population is used as a sample. The results showed that Islamic leadership had a positive effect on work motivation. Islamic work ethic has a positive effect on work motivation. Islamic leadership has a positive effect on performance. Islamic work ethic has a positive effect on performance. Work motivation can mediate between Islamic leadership and performance and work motivation can mediate between Islamic work ethics and performance.
\end{abstract}

\section{Pendahuluan}

Pendidikan merupakan sebuah alat untuk mencerdaskan bangsa. Manusia membutuhkan pendidikan untuk kehidupannya. Manusia dapat menggunakan pendidikan yang telah dia dapatkan untuk memperbaiki kualitas hidupnya. Setiap manusia yang menempuh pendidikan diharapkan mampu mencapai semua cita-cita yang mereka inginkan serta diakui oleh masyarakat lainnya. Penyelenggaraan pendidikan di Indonesia merupakan suatu sistem pendidikan nasional yang diatur secara sistematis. Pendidikan nasional berfungsi mengembangkan kemampuan dan membentuk watak serta peradaban bangsa yang bermartabat dalam rangka mencerdaskan kehidupan bangsa, bertujuan untuk berkembangnya potensi peserta didik agar menjadi manusia yang beriman dan bertaqwa kepada Tuhan Yang Maha Esa, berakhlak mulia, sehat, berilmu, cakap, kreatif, mandiri, dan menjadi warga Negara yang demokratis serta bertanggung jawab.

Guru profesional adalah guru yang mampu bertanggung jawab dengan tugas yang telah diberikan dan memiliki beberapa kompetensi. Kompetensi yang dimiliki ileh guru mampu menyelesaikan tugasnya dengan baik. Undang-Undang Guru dan Dosen No.14 tahun 2005 Bab IV pasal 10 ayat 1 menjelaskan kompetensi yang harus dimiliki seorang guru meliputi 
kompetensi pedagogik, kompetensi kepribadian, kompentensi sosial, dan kompentesi profesional untuk menjadi guru yang mempunyai kinerja baik untuk mencapai tujuan pendidikan nasional.

Kinerja merupakan sebuah hasil yang dicapai oleh seseorang dalam melaksanakan tugas yang dibebankan padanya yang didasarkan pada kecakapan, pengalaman, dan kesungguhan serta penggunaan waktu untuk mencapai tujuan tertentu. Demikian halnya dengan kinerja guru, dapat dilihat dari kemampuannya memberikan harapan dan keinginan semua pihak terutama masyarakat umum yang telah mempercayai sekolah dan guru dalam membina anak didiknya.

Menurut Rivai (2010: 309) kinerja merupakan perilaku nyata yang ditampilkan setiap orang sebagai prestasi kerja yang dihasilkan oleh pegawai sesuai dengan perannya dalam perusahaan. Istilah kinerja juga sering disebut performance. Ada beberapa pandangan yang membahas tentang kinerja, walaupun definisi kinerja dapat diartikan dengan berbagai arti, namun dalam hal ini diuraikan tentang definisi dari kinerja. Kinerja pegawai merupakan hasil dari kerja pegawai baik secara kualitas maupun kuantitas yang dicapai oleh seorang pegawai dalam melaksanakan tugasnya sesuai dengan tanggung jawab yang diberikannya Mangkunegara (2002: 33).

Kinerja guru yang baik merupakan perwujudan kerja yang dilakukan oleh guru yang biasannya dipakai sebagai dasar penilaian terhadap anggota dan organisasi, sehingga perlu diupayakan untuk meningkatkan kinerja untuk meningkatkan kualitas lulusan yang akan berdampak pada perbaikan sumber daya manusia nantinya.

MTs Negeri 5 Kebumen merupakan salah satu sekolah yang beralamat di desa Klirong Kecamatan Klirong Kab Kebumen tepatnya di sebelah selatan pertigaan jalan raya terletak didekat Polsek Klirong dan SDN Klirong. MTs Negeri 5 Kebumen merupakan sekolah yang berakreditasi A dan salah satu sekolah yang memiliki prestasi yang baik dari segi akademis maupun non akademis.

Berdasarkan hasil observasi dan wawancara menunjukan bahwa kinerja guru MTs Negeri 5 Kebumen semakin meningkat. Hal ini dapat dilihat administrasi guru yang sudah dilaksanakan dengan baik oleh masing-masing guru MTs Negeri 5 Kebumen berupa silabus dan rencana pelaksanaan pembelajaran (RPP) yang memuat identitas mata pelajaran, standar kompetensi (SK), kompetensi dasar (KD), indikator, tujuan pembelajaran penilaian dan sumber belajar. Selain hal tersebut, kedisiplinan guru MTs Negeri 5 Kebumen sudah sangat baik, hal tersebut dapat dilihat dari ketelambatan guru yang semakin sedikit, dan jika masih tetap ada yang berulang datang terlambat akan mendapatkan nasihat dari kepala sekolah. Kinerja pada guru MTs Negeri 5 Kebumen dinyatakan baik tidak hanya dari hal di atas tetapi juga penilaian kinerja yang dilakukan pada setiap tahunnya yang mengalami peningkatan.

Peningkatan kinerja guru yang ada di MTs Negeri 5 Kebumen menjadi fenomena yang penting untuk diteliti. Faktor-faktor yang diduga berpengaruh terhadap kinerja guru antara lain kepemimpinan islami, etika kerja islam, dan motivasi kerja.

Faktor yang diduga berpengaruh terhadap kinerja salah satunya yaitu kepemimpinan islami. Menurut Wijayanti dan Wadji (2012), kepemimpinan islami adalah kepemimpinan yang selalu berpegang atau didasarkan kepada ketentuan atau ajaran-ajaran yang terdapat 
dalam Al-Qur'an dan Hadist. Kepemimpinan islami merupakan proses atau cara memengaruhi dari seorang pimpinan kepada bawahannya yang ditujukan untuk mencapai tujuan organisasi dimana cara memengaruhi tersebut didasarkan pada aturan-aturan yang terdapat dalam Al-Qur'an dan hadits.

Berdasarkan hasil observasi dan wawancara pada beberapa guru di MTs Negeri 5 Kebumen, kepala sekolah menjalankan kepemimpinannya sesuai dengan ajaran islam. Hal tersebut dibuktikan dengan selalu menyampaikan hal-hal yang penting seperti masalah keuangan kepada guru di MTs Negeri 5 Kebumen. Kepala sekolah yang menyampaikan informasi keuangan kepada guru bertujuan agar guru dapat memahami kondisi keuangan yang ada di MTs Negeri 5 Kebumen dan guru juga dapat yakin bahwa kepala sekolah selalu jujur dan amanah. Selain hal tersebut, kepala sekolah juga mengajak guru untuk memahami lebih dalam ilmu agama islam agar mereka di sana tidak hanya bekerja tetapi juga paham ilmu agama islam. Kepala sekolah juga menerapkan sholat dhuhur berjamaah untuk semua guru dan siswanya, menghafalkan Al-Qur'an jus amma untuk kelas tujuh, menghafalkan AlQur'an surat yassin untuk kelas delapan dan menghafal Al-Qur'an surat Al Waqiah untuk kelas sembilan. Selain hal tersebut, pada setiap koridor sekolah juga terdapat tulisan motivasi dan petingnya ilmu yang dikutip dari hadist dan Al-Qur'an. Hal tersebut menunjukan bahwa kepala sekolah menginginkan bahwa guru dan siswanya untuk selalu bersemangat untuk bekerja dan belajar sesuai dengan ajaran islam.

Faktor lain yang dapat mempengaruhi kinerja yaitu etika kerja islam. Menurut Ahmad,Set.al mendefinisikan etika kerja Islam adalah sebagai seperangkat nilai atau sistem kepercayaan yang diturunkan dari Al-Qur'an dan Sunnah/Hadist mengenai kerja dan kerja keras. Etika kerja didefinisikan sebagai seperangkat sikap atau pandangan mendasar yang dipegang sekelompok manusia untuk menilai bekerja sebagai suatu hal yang positif bagi peningkatan kualitas kehidupan sehingga mempengaruhi perilaku kinerjanya. Guru yang bekerja berdasarkan etika akan mengedepankan nilai-nilai yang tertera pada Al-Qur'an dan Sunnah/Hadist tidak hanya untuk kepentingan diri tetapi semata untuk mencari ridho dari Alloh SWT sehingga dalam bekerja selalu diberi kemudahan.

Guru MTs Negeri 5 Kebumen yang bekerja dengan mengedepankan nilai kaidah islam dalam proses mengajar mereka selalu memberikan contoh yang baik kepada siswanya saat pembelajaran sedang berlangsung ataupun diluar jam mengajar. Selain itu tata tertib yang berlaku MTs Negeri 5 Kebumen yaitu setiap guru dan staf lain memiliki kewajiban yang harus dipatuhi seperti harus bersikap dan bertindak sesuai syariah dan akhlaq Islam, menaati kode etik pegawai berdasarkan peraturan perundangan yang berlaku, melaksanakan tugas dalam belajar mengajar dengan kesungguhan hati, disiplin, tekun, jujur, cermat, sopan santun dan penuh tanggung jawab.

Faktor lain yang dapat mempengaruhi kinerja ialah motivasi kerja. Motivasi kerja menurut Terry Mitchell (dalam Werner dan DeSimone, 2006:48) didefinisikan sabagai proses psikologis yang menyebabkan timbulnya tindakan, yang memiliki arah dan terus menerus untuk mencapai tujuan. Wexley and Yukl (1992:75), mengemukakan bahwa motivasi kerja adalah sesuatu yang menimbulkan semangat atau dorongan kerja. Oleh sebab itu motivasi kerja biasa disebut pendorong semangat kerja. Motivasi kerja guru yang tinggi akan memberikan dampak positif dalam proses belajar mengajar. Selain itu pemberian reward atau kompensasi kepada guru yang memiliki prestasi dalam mengajar akan memotivasi guru untuk bekerja lebih baik dalam kegiatan mengajar agar siswa lebih semangat dalam 
belajar. hal tersebut sesuai dengan penelitian yang dilakukan oleh Vernadat et al. (2013) yang menyatakan bahwa kompensasi efektif dalam memotivasi pegawai. Selain itu motivasi yang tinggi juga akan berpengaruh pada kinerja yang tinggi pula, hal tersebut dapat didilihat bahwa seorang guru yang berkerja dengan motivasi yang tinggi akan melahirkan siswa-siswa yang berprestasi karena seorang guru akan mengajarkan dengan penuh kesabaran sampai siswa itu paham. Motivasi kerja yang baik akan memberikan dorongan semangat tersendiri untuk guru sehingga kinerja guru akan semakin baik.

\section{Kajian Teori dan Telaah Literatur}

\section{Kinerja}

Menurut Rivai (2010: 309) kinerja merupakan perilaku nyata yang ditampilkan setiap orang sebagai prestasi kerja yang dihasilkan oleh pegawai sesuai dengan perannya dalam perusahaan. Istilah kinerja juga sering disebut performance. Ada beberapa pandangan yang membahas tentang kinerja, walaupun definisi kinerja dapat diartikan dengan berbagai arti, namun dalam hal ini diuraikan tentang definisi dari kinerja. Kinerja pegawai merupakan hasil dari kerja pegawai baik secara kualitas maupun kuantitas yang dicapai oleh seorang pegawai dalam melaksanakan tugasnya sesuai dengan tanggung jawab yang diberikannya Mangkunegara (2002: 33). Dharma dan Haedar (2010:32) menjelaskan bahwa kinerja merupakan sesuatu yang dikerjakan atau produk/jasa yang dihasilkan atau diberikan seseorang atau sekelompok orang. Gibson (2007:70) secara singkat menjelaskan bahwa, kinerja (performance) merupakan hasil yang sangat diinginkan dari perilaku. Lopez (dalam Faqih,2011), mengartikan kinerja sebagai hasil dari usaha seseorang yang dicapai dengan adanya kemampuan dan perbuatan dalam situasi tertentu. menurut Robbins (2006:260) Kinerja terdiri dari lima indikator yang dapat diukur yaitu Kualitas, Kuantitas, Ketepatan waktu, Efektivitas, Kemandirian.

\section{Motivasi Kerja}

Menurut Hamzah (2007) mengemukakan bahwa motivasi berasal dari kata motif, yang berarti sebagai kekuatan yang terdapat dalam diri individu, yang menyebabkan individu tersebut bertindak atau berbuat. Motif tidak dapat diamati secara langsung, akan tetapi dapat diinterpretasikan dalam tingkah lakunya, berupa rangsangan dorongan, atau pembangkit tenaga munculnya suatu tingkah laku tertentu. Menurut Bittel \& Newstron dalam Kartika \& Kaihatu, (2010) Motivasi kerja merupakan proses yang menyebabkan seseorang berperilaku dengan cara tertentu dalam rangka memenuhi kebutuhan yang sangat individu untuk bertahan hidup, keamanan, kehormatan, pencapaian, kekuasaan, pertumbuhan dan rasa harga diri. Wexley and Yukl (1992 : 75), mengemukakan bahwa motivasi kerja adalah sesuatu yang menimbulkan semangat atau dorongan kerja. Oleh sebab itu motivasi kerja biasa disebut pendorong semangat kerja. Menurut Maulana (2015) Motivasi Kerja terdiri dari empat indikator yang dapat diukur yaitu Tanggung jawab, Penghargaan, Pekerjaan itu sendiri, Pengembangan dan kemajuan. 


\section{Kepemimpinan Islami}

Menurut Ahmad (2011) Kepemimpinan atau leadership dalam bahasa Arab disebut dengan khilafah. Kepemimpinan Islam dalam suatu organisasi diperoleh dari sumber-sumber Islami yang kemudian diaplikasikan dalam organisasi dengan kepercayaan dan praktek secara Islami berdasarkan Al-Qur'an dan Sunnah. Menurut Hossain dalam Ahmad (2011) Prinsip kepemimpinan berdasarkan Al-Qur'an dan Sunnah bukanlah suatu hal yang terbilang baru di lapisan masyrakat. Namun, hal tersebut lebih menekankan kepada kita tentang kembalinya pemikiran hati dan nurani yang bersumber pada Al-Qur'an dan Sunnah serta menerapkannya pada seluruh aspek kehidupan. Menurut Hakim (2012) Kepemimpinan Islami terdiri dari empat indikator yang dapat diukur yaitu Shidiq (jujur), Amanah (dapat dipercaya), Fathonah (cerdas), Tabligh (menyampaikan).

\section{Etika Kerja Islam}

Triyuwono mengemukakan etika terekspresikan dalam bentuk Syari'ah, yang terdiri dari Al Qur'an, Hadits, Ijma' dan Qiyas. Didasarkan pada sifat keadilan, Etika Syari'ah bagi umat Islam berfungsi sebagai sumber untuk membedakan mana yang benar (haq) dan yang buruk (bathil). Sementara itu etika kerja Islam muncul ke permukaan, dengan landasan bahwa Islam adalah agama yang sempurna. Islam merupakan kumpulan aturan-aturan ajaran (doktrin) dan nilai-nilai yang dapat menghantarkan manusia dalam kehidupannya menuju tujuan kebahagiaan hidup baik di dunia maupun di akhirat (Panuju, 1995: 2). Menurut Ali \& Al-owaihan (2006) etika kerja islam adalah orientasi yang membentuk dan mempengaruhi keterlibatan dan partisipasi penganutnya ditempat kerja. Etika kerja islam memandang kerja sebagai sarana untuk meningkatkan kepentingan diri secara ekonomi, sosial dan psikologi, untuk mempertahankan prestise sosial, untuk memajukan kesejahteraan masyarakat dan menegaskan kembali iman, konsep awalnya yaitu berasal dari al-Qur'an dan Sunnah atau perkataan Nabi Muhammad SAW. Menurut Ali (dalam Sulistyowati,2014) Etika Kerja Islam terdiri dari empat indikator yang dapat diukur yaitu Berusaha (effort),Persaingan (competition), Keterbukaan (transparency), Moralitas (morality)

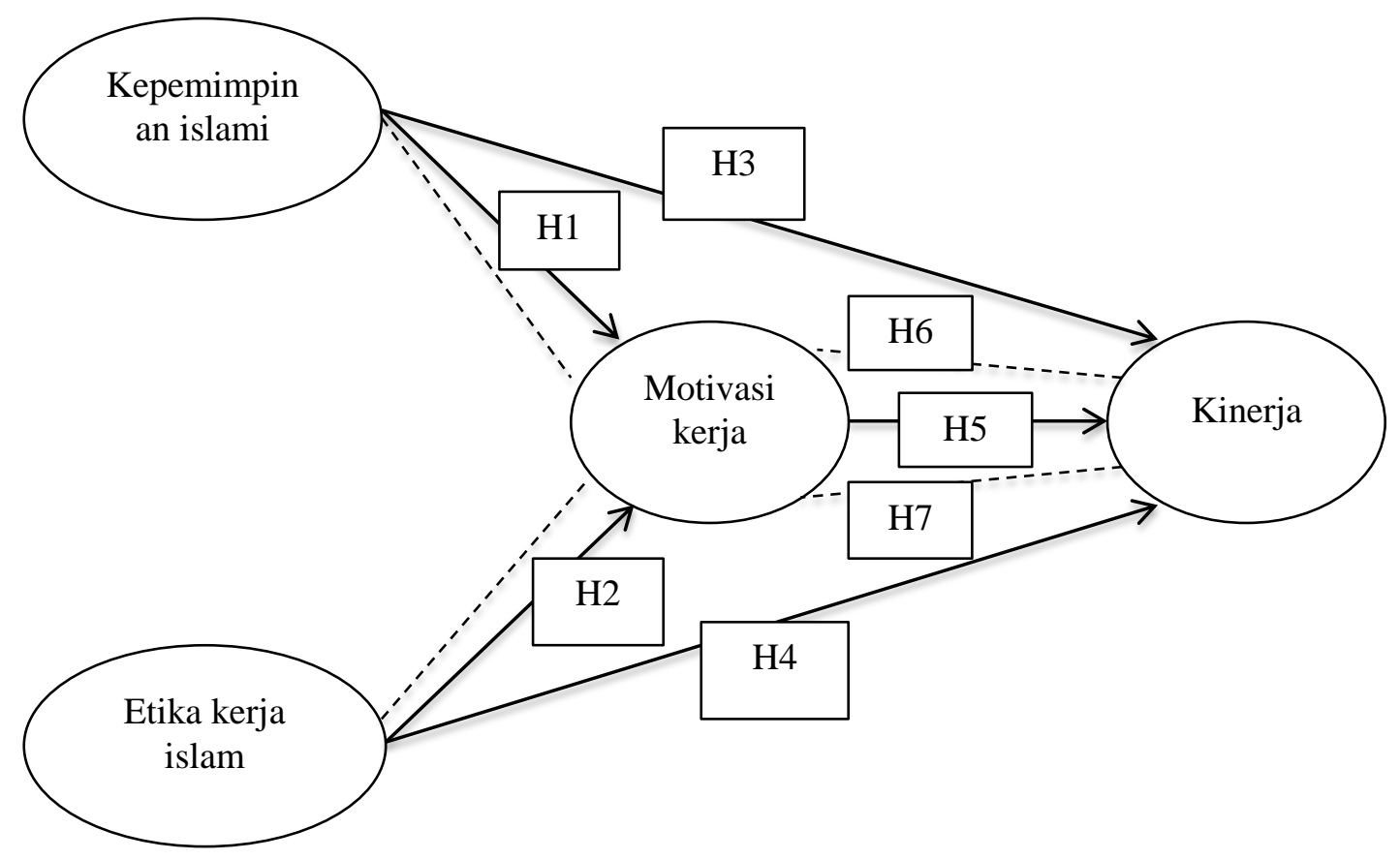

Gambar 1. Model Penelitian 
H1 : Kepemimpinan Islami berpengaruh signifikan dan positif tehadap motivasi kerja.

H2 : Etika kerja islam berpengaruh signifikan dan positif terhadap motivasi kerja.

H3 : Kepemimpinan islami berpengaruh signifikan dan positif tehadap kinerja.

H4 : Etika kerja islam berpengaruh signifikan dan positif terhadap kinerja.

H5 : Motivasi kerja berpengaruh signifikan dan positif tehadap kinerja.

H6 : Kepemimpinan Islami berpengaruh signifikan dan positif terhadap kinerja dengan motivasi kerja sebagai variabel intervening.

H7 : Etika kerja islam berpengaruh signifikan dan positif terhadap kinerja dengan motivasi kerja sebagai variabel intervening.

\section{Metode Penelitian}

Rancangan penelitian ini menggunakan pengujian hipotesis dan penelitian ini menggunakan jenis penelitian kuantitatif. Populasi pada penelitian ini adalah guru MTs Negeri 5 Kebumen yang berjumlah 48 orang. Dalam penelitian ini penulis menggunakan sampel jenuh karena jumlah responden yang relatif kecil sehingga jumlah seluruh populasi digunakan sebagai sampel.

Teknik pengmpulan data yang dilakukan dengan cara : (1) Menyebar langsung kuisioner langsung kepada guru MTs Negeri 5 Kebumen, (2) wawancara, (3) Studi Pustaka. Instrumen dalam penelitian ini dilakukan dengan menggunakan kuisioner yang ditujukan untuk memperoleh jawaban dari responden. Alat bantu pengolahan data menggunakan SPSs for windows. Teknik analisis data dilakukan dengan dua cara yaitu analisis deskriptif dan analisis statistika. Analisis data secara statistika meliputi : (1) Uji Validitas dan Reliabilitas, (2) Uji Asumsi Klasik, (3) Uji Hipotesis, (4) Analisis Korelasi, (5) Analisis Jalur, (6) Uji Sobel.

\section{Hasil dan Pembahasan}

\section{Uji Validitas}

Suatu kuisioner dinyatakan valid apabila pertanyaan dalam kuisioner tersebut dapat menggambarkan sesuatu yang akan diukur oleh kuisioner tersebut. Alat ukur atau butir kuesioner dinyatakan valid apabila nilai corrected item total correlation (r-hitung) adalah lebih besar bila dibandingkan dengan rtabel dengan tingkat signifikan lebih kecil dari 0,05.

Tabel 1. Hasil Uji Validitas

\begin{tabular}{lccc}
\hline \multicolumn{1}{c}{ varibel } & butir & sign & status \\
\hline $\begin{array}{l}\text { Kepemimpinan } \\
\text { islami }\end{array}$ & 6 & Signifikan & valid \\
Etika kerja islam & 8 & Signifikan & Valid \\
Motivasi kerja & 5 & Signifikan & Valid \\
kinerja & 7 & signifikan & Valid \\
\hline
\end{tabular}

Sumber: Data Primer Diolah 2021 
Hasil uji validitas seluruh pernyataan yang digunaka dalam variabel Kepemimpinan Islami, Etika Kerja Islam, Motivasi Kerja, dan Kinerja dinyatakan valid.

\section{Uji Reliabilitas}

Suatu kuesioner dikatakan reliable atau handal jika jawaban seseorang terhadap pertanyaan adalah konsisten atau stabil dari waktu ke waktu. Pengukuran relibilitas dapat dilakukan dengan one shot dan kemudian hasilnya dibandingkan dengan pertanyaan lain atau mengukur korelasi antar jawaban pertanyaan. Alat untuk mengukur reliabilitas adalah Cronbach Alpha.

Analisis terhadap hasil uji reliabilitas pada penelitian ini dengan menggunakan bantuan programisasi komputer dengan program SPSS 21.0 for windows yang mengacu pada rumus Alpha Cronbach dengan kriteria pengujian uji realibilitas (Ghozali, 2009):

1. Jika Alpha Cronbach $>0,60$ atau $60 \%$, maka butir atau variabel tersebut reliable

2. Jika Alpha Cronbarch <0,60 atau 60\%, maka variabel tersebut tidak reliabel.

Tabel 2. Hasil Uji Reliabilitas

\begin{tabular}{clccc}
\hline No. & \multicolumn{1}{c}{ Variabel } & r kritis & $\begin{array}{c}\text { Cronbach's } \\
\text { Alpha }\end{array}$ & Keterangan \\
\hline 1 & Kepemimpinan Islami & 0,60 & 0,722 & Reliabel \\
2 & Etika Kerja Islam & 0,60 & 0,665 & Reliabel \\
3 & Motivasi Kerja & 0,60 & 0,606 & Reliabel \\
4 & Kinerja & 0,60 & 0,750 & Reliabel \\
\hline
\end{tabular}

Sumber: Data Primer Diolah, Tahun 2021

Hasil uji reliabilitas menunjukkan bahwa kuesioner untuk seluruh variabel penelitian dinyatakan reliabel. Hal ini dilihat dari hasil koefisien cronbach's alpha yang bernilai $>$ dari 0,60 . Nilai cronbach's alpha untuk variabel kepemimpinan islami sebesar 0,722, variabel etika kerja Islam sebesar 0,665, variabel motivasi kerja sebesar 0,606, dan variabel kinerja sebesar 0,750 .

\section{Uji Multikolinearitas}

Tabel 3. Uji Multikolinieritas Substruktural I

\begin{tabular}{|c|c|c|c|}
\hline \multirow{2}{*}{ No } & \multirow{2}{*}{ Variabel Bebas } & \multicolumn{2}{|c|}{ Collinearity Statistics } \\
\hline & & Tolerance & VIF \\
\hline 1 & Kepemimpinan Islami & ,326 & 3,064 \\
\hline 2 & Etika Kerja Islam & ,326 & 3,064 \\
\hline
\end{tabular}

Sumber: Data Primer Diolah, Tahun 2021

Tabel 4. Uji Multikolinieritas Substruktural II

\begin{tabular}{|c|c|c|c|}
\hline \multirow{2}{*}{ No } & \multirow{2}{*}{ Variabel Bebas } & \multicolumn{2}{|c|}{ Collinearity Statistics } \\
\hline & & Tolerance & VIF \\
\hline 1 & Kepemimpinan Islami & ,270 & 3,706 \\
\hline 2 & Etika Kerja Islam & 237 & 4,212 \\
\hline 3 & Motivasi Kerja & ,238 & 4,198 \\
\hline
\end{tabular}

Sumber: Data Primer Diolah, Tahun 2021

Berdasarkan tabel 3 dan 4 di atas dapat diketahui bahwa nilai tolerance lebih besar dari 0,10 dan nilai VIF kurang dari 10, sehingga model regresi tidak terjadi multikolineritas dan dapat dipakai dalam penelitian ini. 


\section{Uji Heteroskedastisitas}

Pengujian ini dilakukan untuk menguji apakah dalam sebuah model regresi terjadi ketidaksamaan varian dan residua disuatu pengamatan ke pengamatan yang lain. Hasil analisis uji heteroskedastisitas diperoleh sebagai berikut:

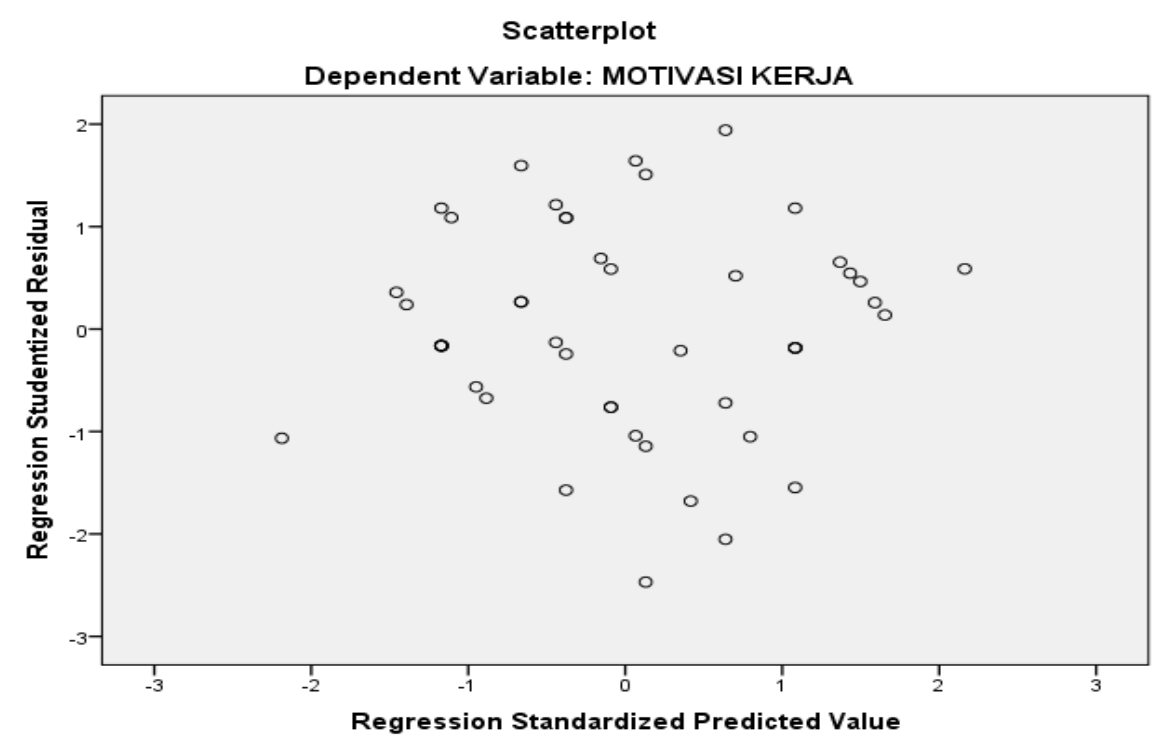

Gambar 2. Hasil Uji Heteroskedastisitas Substruktural I

Sumber: Data Primer Diolah, Tahun 2021

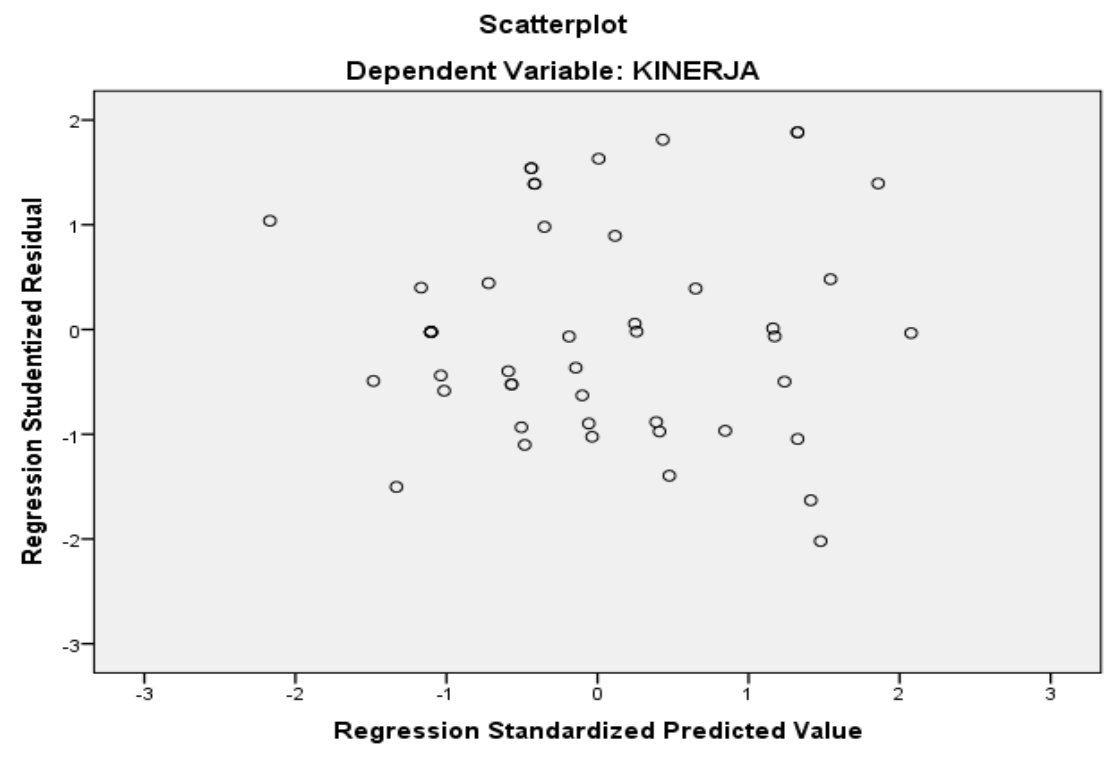

Gambar 3. Hasil Uji Heteroskedastisitas Substruktural II

Sumber: Data Primer Diolah, Tahun 2021

Berdasarkan gambar 2 dan 3 di atas, menunjukan bahwa bulatan-bulatan kecil tidak memiliki pola tertentu, seperti titik-titik atau bulatan yang membentuk suatu pola tertentu yang teratur (bergelombang, melebar, kemudian menyempit) dan tidak ada pola yang jelas sehingga dapat disimpulkan tidak ada gejala heteroskedastisitas model regresi dalam penelitian ini. 


\section{Uji Normalitas}

Uji normalitas bertujuan untuk menguji apakah sebuah model regresi, variable residual memiliki distribusi normal. Hasil analisis uji normalitas diperoleh sebagai berikut:

Tabel 5. Hasil Uji Normalitas Substruktural I

\begin{tabular}{llr}
\hline \multicolumn{2}{c}{ One-Sample Kolmogorov-Smirnov Test } \\
\hline & \multicolumn{2}{c}{$\begin{array}{c}\text { Unstandardiz } \\
\text { ed Residual }\end{array}$} \\
\hline $\mathrm{N}$ & Mean & 48 \\
Normal Parameters &, 0000000 \\
& Std. Deviation &, 74770085 \\
Most Extreme & Absolute &, 112 \\
Differences & Positive &, 072 \\
Kolmogorov-Smirnov Z & Negative &,- 112 \\
Asymp. Sig. (2-tailed) & &, 774 \\
\hline
\end{tabular}

a. Test distribution is Normal.

b. Calculated from data.

Sumber: Data Primer Diolah, Tahun 2021

Tabel 6. Hasil Uji Normalitas Substruktural II

\begin{tabular}{llr}
\hline \multicolumn{2}{c}{ One-Sample Kolmogorov-Smirnov Test } & $\begin{array}{r}\text { Unstandardiz } \\
\text { ed Residual }\end{array}$ \\
\hline $\mathrm{N}$ & Mean & 48 \\
Normal Parametersa,b &, 0000000 \\
& Std. Deviation &, 34454724 \\
Most Extreme & Absolute &, 145 \\
Differences & Positive &, 145 \\
Kolmogorov-Smirnov Z & Negative &,- 100 \\
Asymp. Sig. (2-tailed) & & 1,006 \\
\hline
\end{tabular}

a. Test distribution is Normal.

b. Calculated from data.

Sumber: Data Primer Diolah, Tahun 2021

Berdasarkan tabel 5 dan 6 diketahui bahwa nilai signifikansi Asymp.Sig. (2-tailed) lebih besar dari 0,05. Maka sesuai dengan dasar pengambilan keputusan uji normalitas kolmogorov-smirnov di atas, dapat disimpulkan bahwa data berdistribusi normal. 


\section{Uji Hipotesis}

Tabel 7. Hasil Uji t Substruktural I

\begin{tabular}{|c|c|c|c|c|c|c|}
\hline \multicolumn{7}{|c|}{ Coefficients $^{a}$} \\
\hline \multirow{2}{*}{\multicolumn{2}{|c|}{ Model }} & \multicolumn{2}{|c|}{$\begin{array}{c}\text { Unstandardized } \\
\text { Coefficients }\end{array}$} & \multirow{2}{*}{$\begin{array}{c}\text { Standardized } \\
\text { Coefficients }\end{array}$} & \multirow[t]{2}{*}{$\mathrm{t}$} & \multirow[t]{2}{*}{ Sig. } \\
\hline & & \multicolumn{2}{|r|}{ Error } & & & \\
\hline \multirow[t]{3}{*}{1} & (Constant) & ,599 & 1,417 & & ,423 & ,675 \\
\hline & Kepemimpinan Islami & ,297 & ,097 & ,391 & 3,069 & ,004 \\
\hline & Etika Kerja Islam & ,383 & ,093 &, 523 & 4,106 & ,000 \\
\hline
\end{tabular}

a. Dependent Variable: MOTIVASI KERJA

Sumber: Data Primer Diolah, Tahun 2021

Dari tabel 7 diatas menunjukan bahwa :

1. Probabilitas signifikansi untuk variabel kepemimpinan islami (X1) sebesar $0,004<$ 0,05 dan hasil perhitungan angka thitung sebesar 3,069 > ttabel 2,01410. Hasil ini menyatakan bahwa kepemimpinan islami mempunyai pengaruh positif dan signifikan terhadap motivasi kerja (Y1), maka Ha diterima dan $\mathrm{H} 0$ ditolak.

2. Probabilitas signifikansi untuk variabel etika kerja Islam (X2) sebesar 0,000<0,05 dan hasil perhitungan angka thitung sebesar 4,106 > ttabel 2,01410. Hasil ini menyatakan bahwa etika kerja Islam mempunyai pengaruh positif dan signifikan terhadap motivasi kerja (Y1), maka Ha diterima dan H0 ditolak.

Tabel 8. Hasil Uji t Substruktural II

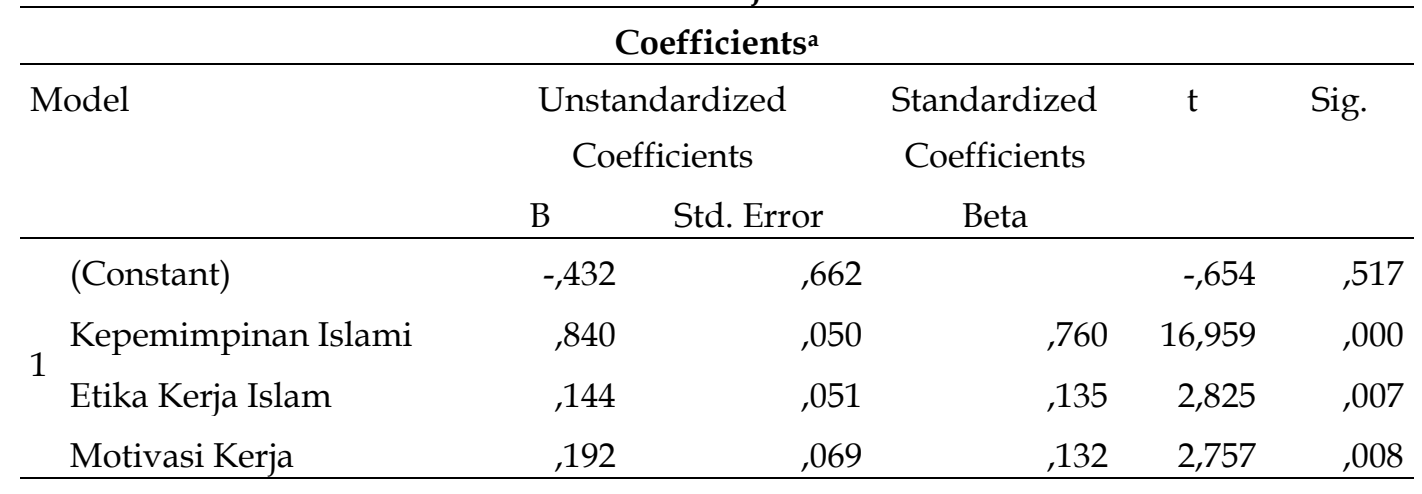

a. Dependent Variable: KINERJA

Sumber: Data Primer Diolah, Tahun 2021

Dari tabel 8 diatas menunjukan bahwa :

1. Probabilitas signifikansi untuk variabel kepemimpinan islami (X1) sebesar 0,000 < 0,05 dan hasil perhitungan angka thitung sebesar 16,959 > ttabel 2,01537. Hasil ini menyatakan bahwa kepemimpinan islami mempunyai pengaruh positif dan signifikan terhadap terhadap kinerja (Y2), maka Ha diterima dan $\mathrm{H} 0$ ditolak.

2. Probabilitas signifikansi untuk variabel etika kerja Islam (X2) sebesar $0,007<0,05$ dan hasil perhitungan angka thitung sebesar 2,825> ttabel 2,01537. Hasil ini menyatakan 
bahwa etika kerja Islam mempunyai pengaruh positif dan signifikan terhadap kinerja (Y2), maka Ha diterima dan $\mathrm{H} 4$ ditolak.

3. Probabilitas signifikansi untuk variabel motivasi kerja (Y1) sebesar 0,008 < 0,05 dan hasil perhitungan angka thitung sebesar 2,757> ttabel 2,01537. Hasil ini menyatakan bahwa motivasi kerja berpengaruh positif dan signifikan terhadap kinerja (Y2), maka Ha diterima dan $\mathrm{H} 0$ ditolak.

\section{Koefisien Determinasi}

Tabel 9. Hasil Output Koefisien Determinasi Struktural I

Model Summaryb

\begin{tabular}{lrrrr}
\hline Model & $\mathrm{R}$ & R Square & Adjusted R Square & Std. Error of the Estimate \\
\hline 1 &, $873^{\mathrm{a}}$ &, 762 &, 751 &, 76414 \\
\hline
\end{tabular}

a. Predictors: (Constant), ETIKA KERJA ISLAM, KEPEMIMPINAN ISLAMI

b. Dependent Variable: MOTIVASI KERJA

Sumber: Data Primer Diolah, Tahun 2021

Berdasarkan Tabel IV-16 hasil pengujian menunjukkan bahwa nilai Adjusted R Square persamaan I sebesar 0,751 artinya kontribusi variabel kepemimpinan islami dan etika kerja Islam terhadap motivasi kerja adalah sebesar $75,1 \%$, sedangkan $24,9 \%(100 \%-75,1 \%)$ dipengaruhi variabel lain di luar model penelitian.

Tabel 10. Hasil Output Koefisien Determinasi Struktural II

Model Summaryb

\begin{tabular}{|c|c|c|c|c|}
\hline Model & $\mathrm{R}$ & R Square & Adjusted R Square & $\begin{array}{l}\text { Std. Error of the } \\
\text { Estimate }\end{array}$ \\
\hline 1 & ,988 & ,976 & ,975 & 35610 \\
\hline
\end{tabular}

Sumber: Data Primer Diolah, Tahun 2021

Berdasarkan Tabel 10 hasil pengujian menunjukkan bahwa nilai Adjusted $\mathrm{R}$ Square persamaan I sebesar 0,975 artinya kontribusi variabel kepemimpinan islami, etika kerja Islam dan motivasi kerja terhadap kinerja adalah sebesar 97,5\%, sedangkan 2,5\% (100\% - 97,5\%) dipengaruhi variabel lain di luar model penelitian. 


\section{Analisis Korelasi}

Tabel 11. Hasil Uji Korelasi

\begin{tabular}{|c|c|c|c|}
\hline \multicolumn{4}{|c|}{ Correlations } \\
\hline & & KEPEMIMPINAN & ETIKA KERJA \\
\hline \multirow{5}{*}{$\begin{array}{l}\text { KEPEMIMPINAN } \\
\text { ISLAMI }\end{array}$} & & ISLAMI & ISLAM \\
\hline & Pearson & 1 &, $821^{* *}$ \\
\hline & Correlation & & \\
\hline & Sig. (2-tailed) & & ,000 \\
\hline & $\mathrm{N}$ & 48 & 48 \\
\hline \multirow{4}{*}{$\begin{array}{l}\text { ETIKA KERJA } \\
\text { ISLAM }\end{array}$} & Pearson &, $821^{* *}$ & 1 \\
\hline & Correlation & & \\
\hline & Sig. (2-tailed) & ,000 & \\
\hline & $\mathrm{N}$ & 48 & 48 \\
\hline
\end{tabular}

Sumber: Data Primer Diolah, Tahun 2021

Berdasarkan tabel 11 di atas, nilai korelasi antara kepemimpinan islami dan etika kerja islam sebesar 0,821 dengan tingkat signifikan 0,000 < 0,05 yang artinya terdapat hubungan atau korelasi yang kuat dan signifikan antara kepemimpinan islami dan etika kerja islam.

\section{Uji Sobel}

\begin{tabular}{|c|c|c|c|c|}
\hline Input: & & Test statistic: & Std. Error: & p-value: \\
\hline 0.297 & Sobel test: & 2.05926375 & 0.02769145 & 0.03946898 \\
\hline$b 0.192$ & Aroian test: & 2.00162754 & 0.02848882 & 0.0453248 \\
\hline$s_{0} 0.097$ & Goodman test: & 2.12218388 & 0.02687043 & 0.0338223 \\
\hline$s_{b} 0.069$ & Reset all & & Calculate & \\
\hline
\end{tabular}

\section{Gambar 4. Hasil Uji Sobel Substruktural II}

Sumber: Data Primer Diolah, Tahun 2021

Hasil uji sobel struktural I menunjukkan p-value atau signifikasi $<0,05$. Hal ini menunjukkan bahwa variabel Kepemimpinan islami berpengaruh terhadap variabel kinerja dengan motivasi kerja sebagai variabel intervening. Artinya variabel motivasi kerja berfungsi sebagai intervening dalam struktural I. 


\begin{tabular}{|c|c|c|c|c|}
\hline Input: & & Test statistic: & Std. Error: & p-value \\
\hline a 0.383 & Sobel test: & 2.30564215 & 0.03189393 & 0.02113064 \\
\hline b 0.192 & Aroian test: & 2.26034583 & 0.03253307 & 0.0237998 \\
\hline$s_{3} 0.093$ & Goodman test: & 2.35377553 & 0.03124172 & 0.01858383 \\
\hline$s_{b} 0.069$ & Reset all & & Calculate & \\
\hline
\end{tabular}

Gambar 5. Hasil Uji Sobel Struktural II

Sumber: Data primer diolah, 2021

Hasil uji sobel struktural II menunjukkan p-value atau signifikasi $<0,05$. Hal ini menunjukkan bahwa variabel etika kerja islam berpengaruh terhadap variabel kinerja dengan motivasi kerja sebagai variabel intervening. Artinya variabel motivasi kerja berfungsi sebagai intervening dalam struktural II.

\section{Pembahasan}

Pengujian hipotesis pertama dilakukan untuk mengatahui pengaruh kepemimpinan terhadap motivasi kerja. Berdasarkan hasil penilitian, menunjukkan bahwa nilai thitung sebesar 3,069 > ttabel 2,01410 dan tingkat signifikansi sebesar 0,004 < 0,05. Hasil ini menyatakan bahwa kepemimpinan islami mempunyai pengaruh positif terhadap motivasi kerja pada guru MTs Negeri 5 Kebumen. Hal ini berarti semakin tinggi Kepemimpinan islami maka akan semakin tinggi pula tingkat Motivasi kerja pada guru MTs Negeri 5 Kebumen. Hasil penelitian ini sejalan dengan hasil penelitian oleh Rezy Aziz (2014) yang menyatakan bahwa terdapat pengaruh yang signifikan antara kepemimpinan islami dengan motivasi kerja. Hasil penelitian ini bertentangan dengan penelitian yang dilakukan Aulia (2019) yang menyatakan bahwa kepemimpinan islami tidak berpengaruh terhadap motivasi kerja.

Adanya pengaruh kepemimpinan Islami terhadap motivasi menunjukkan bahwa seorang pemimpin dalam menjalankan tugasnya berdasarkan pada syariat Islam dapat memberikan dan menciptakan suatu motivasi pada karyawannya sehingga dalam melaksankan pekerjaannya akan lebih semangat. Penerapan kepemimpinan Islami oleh kepala madrasah sudah sesuai dengan keyakinan guru dan berjalan dengan baik, dapat dinilai sudah optimal dan kepemimpinan yang diterapkan sudah selaras dengan ajaran Islam.

Pengujian hipotesis kedua dilakukan untuk mengatahui pengaruh etika kerja Islam terhadap Motivasi kerja. Berdasarkan hasil penilitian, menunjukkan bahwa nilai thitung sebesar 4,106 $>$ ttabel 2,01410 dan tingkat signifikansi sebesar 0,000 < 0,05. Hasil ini menyatakan bahwa etika kerja Islam berpengaruh positif terhadap Motivasi kerja pada guru MTs Negeri 5 Kebumen. Hal ini berarti semakin tinggi etika kerja islam maka semakin tinggi juga tingkat motivasi kerja pada guru MTs Negeri 5 Kebumen. Hasil penelitian ini sejalan dengan penelitian yang dilakukan Rani Kiki Nugraheni menyatakan bahwa etika kerja islam berpengaruh secara parsial terhadap motivasi kerja islam.

Guru MTs Negeri 5 Kebumen selalu diajarkan untuk selalu bekerja sesuai syariat, tidak melanggar aturan, mampu bekerja sama dan menjaga hubungan baik dengan rekan 
kerjanya. Dengan melaksanakan hal tersebut akan meningkatkan etika kerja islam pada setiap guru yang bekerja di madrasah. Etika kerja islam muncul dari dalam diri individu secara naluriah, sehingga seseorang yang memiliki etika kerja islam yang tinggi akan memiliki motivasi kerja yang tinggi. Etika kerja islam akan mendorong atau memotivasi seseorang untuk berkerja lebih baik. Bekerja juga akan dilandasi oleh ajaran-ajaran agama yang dianut dan diyakini kebenarannya. Islam sangat menghargai orang yang bekerja. Sehingga begitu besarnya makna kerja dalam Islam dianggap sebagai salah satu bentuk jihad atau berjuang di jalan Alloh swt.

Pengujian hipotesis ketiga dilakukan untuk mengatahui pengaruh kepemimpinan islami terhadap kinerja. Berdasarkan hasil penilitian, menunjukkan bahwa nilai thitung sebesar $16,959<$ ttabel 2,01537 dan tingkat signifikansi sebesar 0,000 < 0,05. Hasil ini menyatakan bahwa kepemimpinan islami mempunyai pengaruh positif terhadap kinerja guru MTs Negeri 5 Kebumen. Hal ini berarti semakin tinggi kepemimpinan islami maka semakin tinggi kinerja pada MTs Negeri 5 Kebumen.

Kepemimpinan islami dapat memberikan pengaruh pada kinerja, seorang pemimpin akan selalu adil dan menjadi pemeran penting atau contoh untuk setiap bawahannya. Dengan kata lain, seorang pemimpin islami mampu menyadarkan para bawahanya untuk berfikir tentang setiap hasil itu didasarkan atas kehendak Allah swt. Hasil penelitian ini sejalan dengan Ratna Wijayanti dan Meftahudin (2016) yang menyatakan bahwa kepemimpinan islami berpengaruh positif dan signifikan terhadap kinerja. Hasil penelitian ini sejalan dengan penelitian yang dilakukan Sunarji Harahap (2016) yang menyatakan bahwa kepemimpinan Islami(X1) berpengaruh positif terhadap kinerja karyawan. Hasil penelitian ini bertentangan dengan penelitian yang dilakukan oleh Miftachul Jannah, dkk (2015) yang menyatakan bahwa gaya kepemimpinan islam (X1) tidak terdapat pengaruh positif terhadap kinerja (Y2).

Pengujian hipotesis keempat dilakukan untuk mengatahui pengaruh etika kerja Islam terhadap kinerja. Berdasarkan hasil penilitian, menunjukkan bahwa nilai thitung sebesar 2,825 > ttabel 2,01537 dan tingkat signifikansi sebesar 0,007 <0,05. Hasil ini menyatakan bahwa etika kerja Islam berpengaruh positif terhadap kinerja guru MTs Negeri 5 Kebumen. Hal ini berarti semakin tinggi etika kerja Islam maka semakin tinggi pula kinerja guru MTs Negeri 5 Kebumen. Hasil penelitian ini sejalan dengan penelitian yang dilakukan oleh Mc. Mifrohul Hana dan M. Nur Ghufron (2015) menyatakan bahwa etika kerja Islam berpengaruh positif dan signifikan terhadap kinerja karyawan.

Etika kerja islam selalu mengutamakan kepentingan bersama sehingga dalam bekerja akan mendahulukan kepentingan umum dari pada kepentingan pribadi. Penerapan etika kerja Islam sesuai dengan prinsip syari'ah sehingga bisa menciptakan dan menanamkan rasa ikhlas dalam bekerja dan selalu mendahulukan kepentingan umum dari pada kepentingan pribadi untuk mencapai hasil kerja yang lebih baik.

Etika selalu menjadi inti ajaran yang harus diikuti dan diterapkan dalam kehidupan seharihari. Etika kerja Islam menyatakan bahwa hidup tanpa kerja keras adalah tidak berarti dan melaksanakan aktivitas ekonomi adalah sebuah kewajiban. Nilai-nilai agama di dalam bekerja yang terimplementasi dalam sikap dan perilaku kerja yaitu dapat membedakan mana yang baik dan buruk, bermanfaat dan tidak bermanfaat maka akan mengantarkan seorang individu mencapai kinerja terbaik. 
Pengujian hipotesis kelima dilakukan untuk mengatahui pengaruh motivasi kerja terhadap kinerja. Berdasarkan hasil penilitian, menunjukkan bahwa nilai thitung sebesar 2,757 > ttabel 2,01537 dan tingkat signifikansi sebesar 0,008 < 0,05. Hasil ini menyatakan bahwa Motivasi Kerja berpengaruh positif terhadap kinerja guru MTs Negeri 5 Kebumen. Hal ini berarti semakin tinggi Motivasi kerja maka akan semakin tinggi pula kinerja guru MTs Negeri 5 Kebumen. Hasil penelitian ini sejalan dengan penelitian yang dilakukan oleh Sunarji Harahap (2016) yang menyatakan bahwa motivasi kerja berpengaruh positif dan signifikan terhadap kinerja.

Motivasi memiliki pengaruh yang sangat tinggi bagi seseorang pada saat melakukan pekerjaan. Motivasi berasal dari dalam diri sendiri (intrinsik) serta berasal dari luar (ekstinsik) karena adanya rangsangan dari pihak lain, sehingga menimbulkan usaha dan kemauan keras dalam mencapai tujuan tertentu. Guru MTs Negeri 5 Kebumen memiliki motivasi yang tinggi dalam bekerja hal tersebut dilihat dari tanggung jawab terhadap pekerjaan yang dijalani serta pengakuan keberadaan guru di madrasah juga mendorong motivasi kerja yang tinggi.

Pengujian hipotesis keenam dilakukan untuk mengatahui pengaruh kepemimpinan islami terhadap kinerja melalui Motivasi kerja. Berdasarkan hasil analisis jalur diketahui pengaruh langsung yang diberikan kepemimpinan islami (X1) terhadap kinerja (Y2) sebesar 0,760. Pengaruh tidak langsung kepemimpinan islami terhadap kinerja melalui Motivasi kerja yaitu $0,391 \times 0,132=0,052$ dan pengaruh totalnya adalah $0,391+0,132=0,523$. Berdasarkan hasil perhitungan tersebut dapat diketahui bahwa nilai pengaruh tidak langsung 0,052 lebih kecil dibandingkan dengan pengaruh langsung 0,760. Hal ini menunjukkan bahwa secara langsung kepemimpinan islami (X1) melalui motivasi kerja (Y1) mempunyai pengaruh langsung terhadap kinerja (Y2) pada guru MTs Negeri 5 Kebumen.

Berdasarkan hasil uji yang digunakan dengan kalkulator sobel menunjukkan bahwa test statistic > ttabel yaitu 2,05926 > 2,01537 dan p-value < a yaitu 0,0394 < 0,05. Hasil perhitungan tersebut menunjukkan bahwa motivasi kerja dapat memediasi antara variabel kepemimpinan islami dengan variable kinerja pada guru MTs Negeri 5 Kebumen. Hasil penelitian ini bertentangan dengan penelitian yang dilakukan oleh Aulia (2019) menyatakan bahwa Kepemimpinan islam tidak berpengaruh terhadap kinerja karyawan dimediasi motivasi kerja. Motivasi kerja bisa digunakan sebagai variabel penghubung atau variabel intervening dalam sebuah penelitian hal tersebut dapat dilihat dari penelitian yang dilakukan oleh Gunawan (2016) menyatakan bahwa motivasi kerja sebagai variabel intervening antara kompetensi terhadap kinerja pegawai. Hal tersebut menyatakan bahwa motivasi kerja berpengaruh positif secara langsung dan signifikan terhadap kinerja.

Pengujian hipotesis ketujuh dilakukan untuk mengatahui pengaruh etika kerja Islam terhadap kinerja melalui Motivasi kerja. Berdasarkan hasil analisis jalur diketahui pengaruh langsung yang diberikan etika kerja Islam (X2) terhadap kinerja (Y2) sebesar 0,135. Pengaruh tidak langsung etika kerja Islam terhadap kinerja melalui Motivasi Kerja yaitu $\mathrm{X} 2 \rightarrow \mathrm{Y} 1 \rightarrow$ $\mathrm{Y} 2=0,523 \times 0,132=0,069$ dan pengaruh totalnya adalah $\mathrm{X} 2 \rightarrow \mathrm{Y} 1 \rightarrow \mathrm{Y} 2=0,523+0,132=0,655$. Berdasarkan hasil perhitungan tersebut dapat diketahui bahwa nilai pengaruh tidak langsung 0,069 lebih kecil dibandingkan dengan pengaruh langsung 0,135. Hal ini menunjukkan bahwa secara langsung etika kerja Islam (X2) melalui Motivasi kerja (Y1) mempunyai pengaruh terhadap kinerja (Y2) pada guru MTs Negeri 5 Kebumen. 
Berdasarkan hasil uji yang digunakan dengan kalkulator sobel menunjukkan bahwa test statistic < ttabel yaitu 2,30564 < 2,01537 dan p-value < a yaitu 0,0211 > 0,05. Hasil perhitungan tersebut menunjukkan bahwa motivasi kerja dapat memediasi antara variabel etika kerja Islam dengan variabel kinerja pada guru MTs Negeri 5 Kebumen. Hasil penelitian ini sejalan dengan penelitian yang dilaksakan oleh Iskandar Zulkarnaen (2017) yang menyatakan bahwa etika kerja Islam dengan mediasi motivasi kerja berpengaruh signifikan terhadap kinerja karyawan.

\section{Penutup dan Saran}

Berdasarkan hasil analisis data kuesioner mengenai kepemimpinan islami dan etika kerja islam terhadap kinerja dengan motivasi kerja sebagai variabel intervening dapat diperoleh hasil sebagai berikut:

1. Berdasarkan data responden hasil kuesioner, dari segi jenis kelamin mayoritas responden berjenis kelamin perempuan, dari segi usia mayoritas responden berusia lebih dari 40 tahun, dari segi pendidikan terakhir mayoritas responden memiliki tingkat pendidikan S1, dan berdasarkan lama bekerja, mayoritas responden memiliki lama kerja lebih dari 15 tahun.

2. Kepemimpinan Islami memiliki pengaruh positif dan signifikan terhadap Motivasi Kerja pada Guru MTs Negeri 5 Kebumen. Semakin tinggi Kepemimpinan Islami maka semakin tinggi Motivasi Kerja pada Guru MTs Negeri 5 Kebumen.

3. Etika Kerja Islam memiliki pengaruh positif dan signifikan terhadap Motivasi Kerja pada Guru MTs Negeri 5 Kebumen. Semakin tinggi Etika Kerja Islam maka semakin tinggi Motivasi Kerja pada Guru MTs Negeri 5 Kebumen.

4. Kepemimpinan Islami memiliki pengaruh positif dan signifikan terhadap kinerja pada Guru MTs Negeri 5 Kebumen. Semakin tinggi Kepemimpinan Islam maka semakin tinggi kinerja pada Guru MTs Negeri 5 Kebumen.

5. Etika Kerja Islam memiliki pengaruh positif dan signifikan terhadap kinerja pada Guru MTs Negeri 5 Kebumen. Semakin tinggi Etika Kerja Islam maka semakin tinggi kinerja pada Guru MTs Negeri 5 Kebumen.

6. Motivasi Kerja berpengaruh positif dan signifikan terhadap kinerja Guru MTs Negeri 5 Kebumen. Semakin tinggi motivasi kerja maka semakin tinggi kinerja Guru MTs Negeri 5 Kebumen.

7. Kepemimpinan Islami berpengaruh positif dan signifikan terhadap Kinerja melalui Motivasi Kerja hal tersebut berarti motivasi kerja dapat memediasi antara variabel kepemimpinan islami dengan variabel kinerja serta menunjukkan bahwa Kepemimpinan Islami dapat dijadikan sebagai variabel yang mampu meningkatkan kinerja pada Guru MTs Negeri 5 Kebumen.

8. Etika Kerja Islam berpengaruh positif dan signifikan terhadap Kinerja melalui Motivasi Kerja hal tersebut berarti motivasi kerja dapat memediasi antara variabel etika kerja islam dengan variabel kinerja serta menunjukkan bahwa etika kerja islam dapat dijadikan sebagai variabel yang mampu meningkatkan kinerja pada Guru MTs Negeri 5 Kebumen.

Penelitian ini cukup dapat mengungkapkan secara keseluruhan faktor yang mempengaruhi Kinerja Guru MTs Negeri 5 Kebumen, penelitian ini hanya terbatas pada faktor 
Kepemimpinan Islami, Etika Kerja Islam, dan Motivasi Kerja. Untuk penelitian selanjutnya tentang Kepemimpinan Islmi dan Etika Kerja Islam, cakupan penelitian hendaknya diperluas sehingga hasil penelitian dapat digeneralisasi. Selain itu perlu mempertimbangkan faktor-faktor lain baik eksternal maupun internal sebagai faktor yang ikut menentukan motivasi kerja.

\section{Referensi}

Akbar, E. E. (2019). Analisis Kualitas Sumber Daya Insani Dan Etika Kerja Islam Terhadap Kinerja Pegawai Perbankan Syariah Kota Bandar Lampung Dengan Motivasi Sebagai Variabel Moderatting. Masters Thesis, UIN Raden Intan Lampung.

Ali, A. J., \& Al-Owaihan, A. (2008). Islamic work ethic: a critical review. Cross cultural management: An international Journal, 15(1).

Aziz, R., \& Shofawati, A. (2014). Pengaruh Kepemimpinan islami dan Budaya organisasi islami Terhadap Motivasi kerja Islami pada UMKM Kulit di Magetan. Jurnal Ekonomi Syariah Teori dan Terapan, 1(6), 399-415.

Chandra, F. K. (2006). Pengaruh Tindakan Supervisi terhadap Kinerja Auditor Internal dengan Motivasi Kerja sebagai Variabel Intervening (Studi Empiris pada PT. Bank ABC). Doctoral dissertation. Program Pascasarjana Universitas Diponegoro.

Fahrullah, A. (2018). Pengaruh Kepemimpinan Islami Terhadap Motivasi, Kinerja, Serta Kesejahteraan Islami. Journal of Islamic Economics, 2, 121-140.

Gunawan, G. (2017). Pengaruh Kompetensi Terhadap Kinerja Pegawai Dan Motivasi Sebagai Variabel Intervening Pada Kantor Uptd Pendapatan Wilayah I Palu. Katalogis, 3(1).

Hakim, A. (2012). The Implementation of Islamic Leadership and Islamic Organizational Culture and Its Influence on Islamic Working Motivation and IslamicPerformance PT Bank Mu'amalat Indonesia Tbk. Employee in the Central Java. Asia Pacific Management Review, 17(1), 77-90.

Hana, M., \& Ghufron, M. N. (2015). Pengaruh Etika Kerja Islam Dan Kepemimpinan Transformasional Terhadap Kinerja Karyawan. Equilibrium Pascasarjana Stain Kudus, 3(2).

Harahap, S. (2017). Pengaruh Kepemimpinan Islami dan Motivasi Kerja Terhadap Kinerja Karyawan Pada PT. Bank Syariah Mandiri, Tbk Kantor Cabang Pembantu Sukaramai Medan. HUMAN FALAH: Jurnal Ekonomi dan Bisnis Islam, 3(2), 253-270.

Hasibuan, M. S. P. (2002). Manajemen Sumber Daya Manusia. Bumi Aksara. Jakarta

Huda, A. M. (2019). Pengaruh Kepemimpinan Islam dan Budaya. Organisasi Terhadap Kinerja Karyawan Dimediasi Motivasi Kerja (Studi Kasus di Yayasan Badan Wakaf Sultan Agung Semarang), Doctoral Dissertation. IAIN Salatiga

Ismanto, K. (2009). Manajemen Syariah: Implementasi TQM dalam Lembaga Keuangan Syariah. Pustaka Pelajar. Yogyakarta. 
Ithri, F. N., \& Cahyono, H. (2018). Pengaruh Budaya Organisasi Dan Gaya Kepemimpinan Islami Terhadap Kinerja Karyawan PT. Bank Pembangunan Daerah Jawa Timur Tbk (Bank Jatim Syariah) Kantor Cabang Surabaya. Jurnal Ekonomika dan Bisnis Islam, 1(2).

Jannah, M., Suwardi, S., \& Iriyanto, S. (2016). ANALISIS KEPEMIMPINAN ISLAM TERHADAP KINERJA KARYAWAN (Studi Kasus Pada PT. Bank Mumalat Indonesia Tbk, Cabang Semarang). Value Added | Majalah Ekonomi dan Bisnis, 12(1).

Kuncoro, M. (2009). Metode Riset Untuk Bisnis \& Ekonomi. Penerbit Erlangga. Jakarta.

Mangkunegara, A. A. P. (2016). Manajemen sumber daya manusia perusahaan. PT. Remaja Rosdakarya.

Moleong, L. J. (2011). Metodologi Penelitian Kualitatif. Bandung: Remaja Rosda Karya

Murniyati, D. (2017). Pengaruh Etika Kerja Islami pada Motivasi Kerja dan Motivasi Kerja pada Kinerja Karyawan (Kasus pada Waroeng Steak and Shake). Doctoral Dissertation. STIE YKPN.

Permatasari, Ajeng Tria. 2018. Analisis Pengaruh Etika Kerja Islam Terhadap Kepuasa Kerja dan Motivasi Kerja Karyawan BNI Syariah di Daerah Istimewa Yogyakarta. Skripsi. Yogyakarta: Universitas Islam Indonesia

Rivai, V., \& Sagala, E. J. (2010). Manajemen Sumber Daya Manusia untuk Perusahaan, dari Teori ke Praktik, Jakarta: PT. Raja Grafindo Persada.

Sarwono, J. (2004). Analisis Jalur untuk Riset Bisnis dengan SPSS: Aplikasi dalam Riset Pemasaran, Keuangan, Manajemen Sumber Daya Manusia dan Kewirausahaan. Bandung: Penerbit Andi.

Setiawan, K. C. (2015). Pengaruh motivasi kerja terhadap kinerja karyawan level pelaksana di divisi operasi PT. Pusri Palembang. Psikis: Jurnal Psikologi Islami, 1(2), 43-53.

Siagian, D., \& Sugiarto, S. (2006). Metode Statistika. Jakarta: Gramedia Pustaka Utama.

Sodiq, A. (2018). Pengaruh Etika Kerja Islam, Kepemimpinan Transformasional Dan Motivasi Kerja Terhadap Kinerja Karyawan Di Kjks Bmt Logam Mulia Grobogan. BISNIS: Jurnal Bisnis dan Manajemen Islam, 6(1), 118-144.

Subhan, M. (2014). Kepemimpinan islami dalam peningkatan mutu lembaga pendidikan islam. TADRIS: Jurnal Pendidikan Islam, 8(1), 125-140.

Triyuwono, I. (2000). Organisasi dan Akuntansi Syari'ah cetakan pertama. Lkis Yogyakarta.

Wijayanti, R. \& Wajdi, F. (2012). Pengaruh Kepemimpinan Islami, Motivasi, dan Kepuasan Kerja Terhadap Kinerja Karyawan dengan Lama Kerja Sebagai Variabel Moderating. Daya Saing, 13(2). 108-115.

Wijayanti, R., \& Meftahudin, M. (2016). Pengaruh kepemimpinan islami, motivasi dan kepuasan kerja terhadap kinerja karyawan dengan lama kerja sebagai variabel moderating. Jurnal Penelitian Dan Pengabdian Kepada Masyarakat UNSIQ, 3(3), 185-192.

Zahro, N. (2005). Pengaruh Gaya Kepemimpinan Terhadap Semangat Kerja Karyawan Pada KUD DAU Malang. Skripsi. Malang: FE. 
Jurnal Ilmiah Mahasiswa Manajemen, Bisnis dan Akuntansi 3(3) Juni 2021

Zulkarnaen, Iskandar, Rina Hastuti. 2017. Pengaruh Religiusitas dan Etika Kerja Islam Terhadap Kinerja Karyawan Melalui Motivasi Kerja Sebagai Variabel Intervening (Studi Kasus pada Rumah Sakit IPHI Pedan). 